\title{
Bereaved parent's satisfaction with home-based pediatric palliative care: Finding from Poland
}

\author{
Aleksandra Korzeniewska-Eksterowicz ${ }^{1,2 *}$, Łukasz Przysło ${ }^{1,2}$, Bogna Kędzierska ${ }^{2,3}$, Małgorzata Cynker-McCarthy², \\ Małgorzata Stolarska ${ }^{2,4}$ and Wojciech Młynarski ${ }^{4}$ \\ ${ }^{1}$ Pediatric Palliative Care Unit, Department of Pediatrics, Oncology, Hematology and Diabetology, Medical University of Lodz, $36 / 50$ Sporna str, 91-738 \\ Łodz, Poland \\ ${ }^{2}$ Gajusz Foundation - Pediatric Palliative Care Centre, Home Hospice for Children of Lodz Region, 17 Piotrkowska str, $90-406$ Lodz, Poland. \\ ${ }^{3}$ Institute of Psychology, University of Lodz 10/12 Smugowa str., 91-433 Lodz, Poland \\ ${ }^{4}$ Department of Pediatrics, Oncology, Hematology and Diabetology, Medical University of Lodz, 36/50 Sporna str, $91-738$ Łodz, Poland
}

\begin{abstract}
Received: February 19, 2014; Accepted: May 28, 2014; Published: June 12, 2014
*Corresponding author: Aleksandra Korzeniewska-Eksterowicz, Pediatric Palliative Care Unit, Department of Pediatrics, Oncology, Hematology and Diabetology 36/50 Sporna str, 91-738 Łodz, Poland, Tel: +48426177791, Fax: +48426177798, Email: aleksandra.korzeniewska-eksterowicz@umed. lodz.pl
\end{abstract}

\begin{abstract}
Background: Measurement of satisfaction with palliative care seems to be a tool evaluating quality of care, especially in pediatric population.
\end{abstract}

Objective: The aim of this study was the evaluation of care based on satisfaction measured among bereaved parents of patients of Home Hospice for Children of Lodz Region.

Methods: An anonymous questionnaire was posted to the parents of 51 children, who died under hospice care between years 2005-2010. Out of 36 questions 27 were divided into 5 domains: general care evaluation, communication with hospice staff, work of basic staff, conditions of social care, preparation for child's death. For standardization of results transformation of raw results in 100-point scale within 0-100 points was conducted.

Results: 42 completely filled questionnaires were returned and 37 were included in the analysis. The most frequently reason to use hospice care was the lack of possibility of further hospital care Respondents asked about their fears connected with decision to use hospice care most frequently said that they wouldn't cope with home care, Main expectations connected with hospice care were minimizing the feeling of helplessness. Total value of children's families satisfaction with hospice care was classified as "very good". Average values in all domains excluding the level of preparation for child's death exceeded 75 points significantly. Among the domains which value was classified as "very good" general satisfaction with care and staff-family communication were top classified.

Conclusions: Measurement of satisfaction with palliative care key element which determines the strategy of organization development

Keywords: Pediatric palliative care, parents, bereavement, satisfaction

\section{Introduction}

Pediatric palliative care (PPC) is an interdisciplinary practice and requires planning and anticipatory guidance. [1-3] one of the models of PPC is home-based model, but unfortunately extremely little data are available on this topic [4-7].

Modern model of PPC includes monitoring and evaluation of that care but the basic problem in the evaluation of palliative care is finding proper criteria. Measurement of satisfaction with palliative care seems to be a tool evaluating quality of care, especially useful with reference to pediatric population $[8,9]$ In PPC due to the patients' age, type of condition, limited possibilities of communication of patient "soft criteria" (evaluation of symptoms control, quality of life) could be difficult or impossible to apply. [10-12] Evaluation of patients' level of satisfaction with medical care raises the interest of Polish and foreign researchers. [4, 10-13]

In Poland PPC has been mainly provided by specialized palliative home care teams and that home-based model of care is called "home hospice". [11,14] Additional to planned physicians' and nurses' visits, patients have access for telephone consultation 24 - hours a day and intervention visits are always a response to the patient's health deterioration. Visits of psychologist, social worker, physiotherapist and chaplain are planned according to individual needs of each family. Home-based PPC, including medical equipments, in Poland is free of charge - all children are insured.

Home Hospice for Children of Lodz Region (HHChLR) was founded in 2005 and since then has been cared for over 180 children. In Lodz Region (over 2,5 mln inhabitants with 471000 children) there is only one more children hospice and the HHChLR looks after $80 \%$ of pediatric population classified for palliative care.

Due to controversy which PPC raises, there is a lack of literature on the satisfaction with that care, especially on home- 
based care. In Poland only one research on this topic has been done so far. [11]

\section{Aim}

The aim of this study is the evaluation of care based on satisfaction measured among bereaved parents of patients of HHChLR.

\section{Material and Methods}

Survey addressed to the parents/carers of all $(n=51)$ children, who died under HHChLR care between years 2005-2010 has been conducted. Anonymous questionnaire was constructed for the needs of this from a comprehensive literature search, review of validated tools, and clinical experience. A group of six families was convened to test face validity. These questionnaires were validated by checking the logical consistency of individual questions, and different wording was used if necessary. Questionnaire was posted to the recipients, enclosing addressed return envelope. In all the cases the time from child's death to the day of mailing the survey was longer than 3 months.

Questionnaire included 36 closed questions and the socio demographic data. Out of 36 questions 27 were divided into 5 domains: general care evaluation (5 questions), evaluation of communication with hospice staff [7], evaluation of work of basic staff - physician, nurse, social worker [6], evaluation of conditions of social care [5], evaluation of the level of preparation for child's death [4]. Job of a chaplain, psychologist, physiotherapist and volunteers required individual evaluation (4 questions) because of the fact that their service is optional. The remaining 5 questions referred to motivation, fears and expectations of families connected with hospice care. Answers to 31 questions evaluating different aspects of provided care were classified in a few-level scale where higher values referred to better evaluation.

\section{Statistical analysis}

For needs of comparative analysis of groups of questions standardization of results through transformation of raw results in 0-100 points scale was conducted, according to formula ${ }^{15}$ :

$$
T R=\frac{R R-M i n}{M a x-M i n} \times 100
$$

TR - Transformed result

\section{RR - Raw result}

Min - Minimal result possible to achieve in the scale

Max - Maximal result possible to achieve in the scale

In the 100-point scale 0 represented the lowest result, 100 the highest one. The range of points from 0 to 25 was classified as negative, the range from 26 to 50 as satisfactory, results between 51 and 75 points as good, and over 75 points as very good.

To compare study variables two-sided exact Fisher and Student's t-test were used. The result in 100-point scale was dichotomised in $75^{\text {th }}$ point and included in the logistic regression analysis as dependent variable. P-values $<0.05$ were considered to be significant. Data was presented as with mean with
95\% confidence interval. All analyses were performed using STATISTICA for Windows release 6.0 software and SPSS 11.5.

This study was approved by the Medical Ethics Committee of the Medical University of Lodz (RNN/419/06/KB).

\section{Results}

Surveys were directed to parents/carers of all hospice patients who died during analysed period. Out of 51 posted questionnaires 42 (82\%) were returned. Out of these 37 correctly completed questionnaires were included in the analysis.

Patients and respondents characteristics are showed in Table 1.

Respondents' motivation, fears and expectations connected with hospice care are shown in Table 2.

Total value of children's families/carers satisfaction with hospice care (the sum of questions in all domains) was classified as "very good". Mean values in all surveyed domains excluding the level of preparation for child's death significantly exceeded 75 points. Detailed results of value of particular domains are presented in Tables 3 and 4.

Out of 37 respondents 15 benefited from spiritual care, 18 of psychological help, 8 of physiotherapist service and 9 of volunteers' support. Almost 30\% of families participated in bereaved support groups. Chaplain's job was evaluated as "good" by the $50 \%$ of respondents, psychologist's job was classified as "very good" by majority of respondents (67\%). No significant relation between value of satisfaction with hospice care and surveyed socio demographic variables (with exception of a domain evaluating basic staff job, where level of satisfaction depended on who filled in the questionnaire) were presented. Evaluation on basic staff job done by grandmothers was more critical than by mothers.

\section{Discussion}

Transition to palliative care - especially when care is planned as home-based model - is the most difficult decision for child and their parents during long period of treatment. Presented study showed main fears connected with decision to be transferred to home hospice care. Results of other studies showed positive effects of hospice intervention and support for children with life-limiting illnesses [4,13,16-18]. In opinion of this study authors home-based model of care should be promoted as most suitable for children and their families, as well as cheaper than the inpatient model of care. This opinion accords with the international trends which emphasise the importance of home-based PPC, especially with psychological and social input. $[2,19,20]$ Care and dying at home becomes more and more possible due to the fast development of the symptom management, development of medical techniques and the advancement of PPC $[4,21,22]$. Main expectations connected with hospice care indicated by respondents are similar to observations of other authors.[4,10,17,23] It is worth noting that in the domain assessing the work of the basic staff respondents evaluated highest effectiveness of the symptoms' management. 
Bereaved parent's satisfaction with home-based pediatric palliative care: Finding from

Poland

Table 1: Respondents and patients characteristics.

\begin{tabular}{|c|c|c|}
\hline & \multicolumn{2}{|c|}{ Respondents' characteristics $(n=37)$} \\
\hline & $\mathbf{n}$ & $\%$ \\
\hline \multicolumn{3}{|l|}{ Degree of consanguinity with child } \\
\hline Mother & 27 & 73 \\
\hline Father & 5 & 13 \\
\hline Grandmother & 5 & 13 \\
\hline \multicolumn{3}{|l|}{ Level of education } \\
\hline Elementary & 0 & 0 \\
\hline Vocational & 14 & 39 \\
\hline Secondary & 21 & 55 \\
\hline Academic & 2 & 6 \\
\hline \multicolumn{3}{|l|}{ Place of living } \\
\hline Village & 15 & 40 \\
\hline Town & 8 & 21 \\
\hline \multirow[t]{2}{*}{ City } & 14 & 39 \\
\hline & \multicolumn{2}{|c|}{ Died patients' characteristics (n=37) } \\
\hline Cause of death & $\mathrm{n}$ & $\%$ \\
\hline Cancer & 27 & 73 \\
\hline Neurologic disorder & 8 & 22 \\
\hline Other life-limiting illness & 2 & 5 \\
\hline \multirow{2}{*}{ Age at the moment of admission to the hospice } & Range (min - max) & Mean \pm SD \\
\hline & 2 months - 18 years & $10,27 \pm 6,2$ years \\
\hline Duration of hospice care & 2 weeks - 31 months & $7,13 \pm 5,4$ months \\
\hline
\end{tabular}

Table 2: Respondents' motivation, fears and expectations connected with hospice care.

\begin{tabular}{|c|c|c|}
\hline \multirow[t]{2}{*}{ Questions and answers' options } & \multicolumn{2}{|c|}{$\begin{array}{l}\text { Number and percentage of respondents } \\
\qquad(n=37)\end{array}$} \\
\hline & $\mathbf{n}$ & $\%$ \\
\hline \multicolumn{3}{|l|}{ Source of information about hospice } \\
\hline Physician & 20 & 54 \\
\hline Parents of other ill children & 8 & 22 \\
\hline Acquaintances & 1 & 3 \\
\hline Mass-media & 3 & 8 \\
\hline Internet & 5 & 13 \\
\hline \multicolumn{3}{|l|}{ Fears connected with decision to apply hospice care ${ }^{*}$} \\
\hline Child will not to be treated & 6 & 14 \\
\hline Child will die faster & 8 & 22 \\
\hline Child would discover the truth abort his disease & 10 & 27 \\
\hline \multicolumn{3}{|l|}{ Strangers will come to our home } \\
\hline We wouldn't cope with home care & 15 & 40 \\
\hline Hospice introduces gloomy mood in our home & 1 & 3 \\
\hline Family/friends/neighbors will have a bad opinion about us & 5 & 13 \\
\hline
\end{tabular}

Citation: Korzeniewska-Eksterowicz A, Przysło Ł, Kędzierska B, Cynker-McCarthy M, Stolarska M, et al. (2014) Bereaved parent's satisfaction with home-based pediatric palliative care: Finding from Poland. Palliat Med Care 1(3): 1-7. DoI: http://dx.doi. 


\begin{tabular}{|c|c|c|}
\hline Causes of decisions about applying hospice care ${ }^{*}$ & & \\
\hline Child wanted to stay home & 6 & 14 \\
\hline Awareness of the lack of possibility of further hospital care & 16 & 43 \\
\hline Difficult conditions of stay in hospital ward & 4 & 11 \\
\hline Chance of being close to the child with family in home & 13 & 37 \\
\hline Others & 3 & 8 \\
\hline \multicolumn{3}{|l|}{ Expectations connected with hospice care ${ }^{*}$} \\
\hline Expectation of limiting child's suffering & 14 & 38 \\
\hline Expectation of child's ensuring their sense of safety & 13 & 37 \\
\hline Minimizing the feeling of helplessness & 17 & 45 \\
\hline Receiving medical help & 16 & 43 \\
\hline Receiving psychological support & 10 & 27 \\
\hline Receiving spiritual support & 7 & 20 \\
\hline Receiving financial support & 4 & 11 \\
\hline Expectation of help connected with settling formalities connected with child's death & 7 & 20 \\
\hline Others & 5 & 13 \\
\hline
\end{tabular}

* Multi choice question - respondents could indicate two options of answers.

Table 3: Detailed results of hospice care satisfaction domains.

\begin{tabular}{|c|c|c|c|c|c|c|c|}
\hline \multirow[b]{2}{*}{ Domains } & \multirow[b]{2}{*}{ Questions } & \multicolumn{5}{|c|}{ Answers and evaluation in 0-4 points scale (raw results) } & \multirow{2}{*}{$\begin{array}{l}\text { Mean results after } \\
\text { transformation to the } \\
100 \text {-points scale. }\end{array}$} \\
\hline & & $\mathbf{0}$ & 1 & 2 & 3 & 4 & \\
\hline \multirow{5}{*}{ 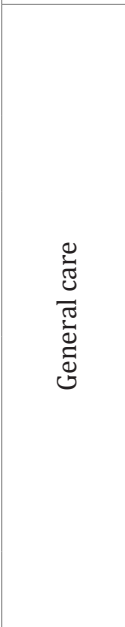 } & $\begin{array}{c}\text { Was the care of child a big } \\
\text { organisational load for your } \\
\text { family? }\end{array}$ & yes & rather yes & on average & rather no & no & 90,16 \\
\hline & $\begin{array}{l}\text { Are you satisfied with } \\
\text { hospice care of child? }\end{array}$ & no & rather no & on average & rather yes & yes & 95,36 \\
\hline & $\begin{array}{c}\text { Did you receive sufficient } \\
\text { information about the care } \\
\text { of child? }\end{array}$ & I didn't receive & $\begin{array}{l}\text { I was not } \\
\text { interested in }\end{array}$ & $\begin{array}{l}\text { information } \\
\text { was sketchy }\end{array}$ & $\begin{array}{c}\text { information } \\
\text { were sufficient }\end{array}$ & $\begin{array}{c}\text { information } \\
\text { were exhaustive }\end{array}$ & 91,12 \\
\hline & $\begin{array}{l}\text { Were there any decisions } \\
\text { made by physicians or other } \\
\text { hospice team members } \\
\text { difficult to accept or } \\
\text { inconsistent with yours } \\
\text { expectations? }\end{array}$ & yes & no & - & - & - & 90,76 \\
\hline & $\begin{array}{l}\text { Was arranging of care } \\
\text { caused difficulty for you? }\end{array}$ & yes & no & - & - & - & 88,65 \\
\hline \multirow{3}{*}{ 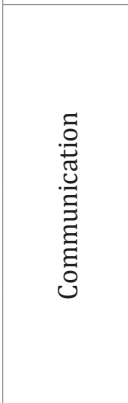 } & $\begin{array}{c}\text { How do you assess first } \\
\text { conversation with hospice } \\
\text { team? }\end{array}$ & $\begin{array}{l}\text { information were } \\
\text { incomprehensible }\end{array}$ & $\begin{array}{l}\text { my anxiety } \\
\text { increased }\end{array}$ & $\begin{array}{l}\text { I was very } \\
\text { nervous } \\
\text { and I don't } \\
\text { remember this } \\
\text { conversation }\end{array}$ & I calmed down & $\begin{array}{l}\text { information } \\
\text { were } \\
\text { comprehensible }\end{array}$ & 89,15 \\
\hline & $\begin{array}{c}\text { Did you satisfied with } \\
\text { communication with hospice } \\
\text { team? }\end{array}$ & no & rather no & on average & rather yes & yes & 92,65 \\
\hline & $\begin{array}{c}\text { Was the number of } \\
\text { conversations with hospice } \\
\text { team sufficient? }\end{array}$ & no & rather no & on average & rather yes & yes & 87,13 \\
\hline
\end{tabular}

Citation: Korzeniewska-Eksterowicz A, Przysło Ł, Kędzierska B, Cynker-McCarthy M, Stolarska M, et al. (2014) Bereaved parent’s satisfaction with home-based pediatric palliative care: Finding from Poland. Palliat Med Care 1(3): 1-7. DoI: http://dx.doi. 


\begin{tabular}{|c|c|c|c|c|c|c|c|}
\hline & $\begin{array}{l}\text { Did you receive sufficient } \\
\text { information about child's } \\
\text { diagnosis? }\end{array}$ & I didn't receive & $\begin{array}{c}\text { I was not } \\
\text { interested in }\end{array}$ & $\begin{array}{c}\text { information } \\
\text { were sketchy }\end{array}$ & $\begin{array}{c}\text { information } \\
\text { were sufficient }\end{array}$ & $\begin{array}{c}\text { information } \\
\text { were exhaustive }\end{array}$ & 89,97 \\
\hline & $\begin{array}{l}\text { Did you receive sufficient } \\
\text { information about child's } \\
\text { disease course and } \\
\text { prognosis? }\end{array}$ & I didn't receive & $\begin{array}{c}\text { I was not } \\
\text { interested in }\end{array}$ & $\begin{array}{c}\text { information } \\
\text { were sketchy }\end{array}$ & $\begin{array}{c}\text { information } \\
\text { were sufficient }\end{array}$ & $\begin{array}{c}\text { information } \\
\text { were exhaustive }\end{array}$ & 90,48 \\
\hline & $\begin{array}{l}\text { Did you receive sufficient } \\
\text { information about the best } \\
\text { for your child lifestyle? }\end{array}$ & I didn't receive & $\begin{array}{c}\text { I was not } \\
\text { interested in }\end{array}$ & $\begin{array}{l}\text { information } \\
\text { were sketchy }\end{array}$ & $\begin{array}{c}\text { information } \\
\text { were sufficient }\end{array}$ & $\begin{array}{c}\text { information } \\
\text { were exhaustive }\end{array}$ & 86,62 \\
\hline & $\begin{array}{l}\text { Did you receive sufficient } \\
\text { information about child's } \\
\text { treatment? }\end{array}$ & I didn't receive & $\begin{array}{c}\text { I was not } \\
\text { interested in }\end{array}$ & $\begin{array}{c}\text { information } \\
\text { were sketchy }\end{array}$ & $\begin{array}{c}\text { information } \\
\text { were sufficient }\end{array}$ & $\begin{array}{c}\text { information } \\
\text { were exhaustive }\end{array}$ & 89,24 \\
\hline \multirow{5}{*}{ 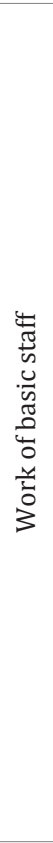 } & $\begin{array}{c}\text { How do you assess } \\
\text { effectiveness of symptoms' } \\
\text { management? }\end{array}$ & $\begin{array}{c}\text { child often } \\
\text { suffered because } \\
\text { management } \\
\text { of the symptoms } \\
\text { was not at all } \\
\text { effective }\end{array}$ & $\begin{array}{l}\text { child suffered } \\
\text { most of the } \\
\text { time and the } \\
\text { management } \\
\text { brought relief } \\
\text { only for a } \\
\text { short period } \\
\text { of time }\end{array}$ & $\begin{array}{c}\text { child rare } \\
\text { suffered and } \\
\text { exacerbations } \\
\text { of symptoms } \\
\text { were able to } \\
\text { control after } \\
\text { the drugs } \\
\text { administration }\end{array}$ & $\begin{array}{l}\text { child was } \\
\text { not suffer } \\
\text { because of } \\
\text { fully effective } \\
\text { management }\end{array}$ & - & 90,17 \\
\hline & $\begin{array}{l}\text { How do you assess support } \\
\text { provided by physicians? }\end{array}$ & poor & fair & good & very good & excellent & 88,40 \\
\hline & $\begin{array}{l}\text { How do you assess support } \\
\text { provided by nurses? }\end{array}$ & poor & fair & good & very good & excellent & 87,12 \\
\hline & $\begin{array}{l}\text { How do you assess support } \\
\text { provided by social worker? }\end{array}$ & poor & fair & good & very good & excellent & 86,04 \\
\hline & $\begin{array}{l}\text { Was the frequency of } \\
\text { hospice team visits } \\
\text { sufficient? }\end{array}$ & no & rather no & on average & rather yes & yes & 85,64 \\
\hline \multirow{4}{*}{ 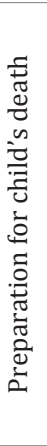 } & $\begin{array}{c}\text { Did you talk with your child } \\
\text { abort the death? }\end{array}$ & no & yes & - & - & - & 50,00 \\
\hline & $\begin{array}{l}\text { Did you feel prepared for } \\
\text { child's death? }\end{array}$ & no & rather no & on average & rather yes & yes & 54,67 \\
\hline & $\begin{array}{l}\text { How do you assess } \\
\text { attendance of hospice team } \\
\text { during the last moments of } \\
\text { child's life? (if applicable) }\end{array}$ & was helpful & $\begin{array}{c}\text { was } \\
\text { embarrassing }\end{array}$ & $\begin{array}{l}\text { I didn't need } \\
\text { that }\end{array}$ & - & - & 65,85 \\
\hline & $\begin{array}{l}\text { How do you assess } \\
\text { assistance from hospice staff } \\
\text { in completing the formalities } \\
\text { after the death of a child? }\end{array}$ & negatively & positively & - & - & - & 59,52 \\
\hline \multirow{3}{*}{ 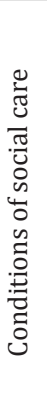 } & $\begin{array}{l}\text { Could the child stay without } \\
\text { any embarrassment in a } \\
\text { separate room (whenever } \\
\text { she/he desires)? }\end{array}$ & no & rather no & on average & rather yes & yes & 83,24 \\
\hline & $\begin{array}{l}\text { Was the home equipment } \\
\text { facilitated the care of child? }\end{array}$ & no & rather no & on average & rather yes & yes & 87,45 \\
\hline & $\begin{array}{l}\text { Did you able to maintain } \\
\text { proper cleanliness of the } \\
\text { premises? }\end{array}$ & no & rather no & on average & rather yes & yes & 88,34 \\
\hline
\end{tabular}




\begin{tabular}{|c|c|c|c|c|c|c|}
\hline $\begin{array}{l}\text { Did your child have easy } \\
\text { access to the toilet? }\end{array}$ & no & yes & - & - & - & 75,30 \\
\hline $\begin{array}{l}\text { How do you access your } \\
\text { financial costs incurred in } \\
\text { connection with the care of } \\
\text { a child at home? }\end{array}$ & $\begin{array}{l}\text { The costs exceed } \\
\text { our capacity, } \\
\text { appropriate care } \\
\text { was not possible } \\
\text { (despite of the } \\
\text { support from the } \\
\text { hospice) }\end{array}$ & $\begin{array}{l}\text { The costs } \\
\text { exceed our } \\
\text { capacity but } \\
\text { appropriate } \\
\text { care was } \\
\text { possible by } \\
\text { support from } \\
\text { the hospice }\end{array}$ & $\begin{array}{c}\text { The costs did } \\
\text { not exceed our } \\
\text { capacity }\end{array}$ & - & - & 91,42 \\
\hline
\end{tabular}

Table 4: Evaluation of hospice care satisfaction presented in the 100-points scale result significantly above 75 points.

\begin{tabular}{|c|c|c|c|c|}
\hline \multicolumn{2}{|c|}{ Domains and range of points in 100 -point scale } & $\begin{array}{c}\text { Number of respondents } \\
(\%) \mathrm{N}=37\end{array}$ & Mean $\pm S D$ (points) & $\begin{array}{l}\text { Minimal-maximum } \\
\text { results (points) }\end{array}$ \\
\hline \multirow{3}{*}{ General care evaluation } & $\begin{array}{l}\text { Satisfactory } \\
(26-50)\end{array}$ & $1(2,7)$ & \multirow{3}{*}{$91,21^{*} \pm 13,80$} & \multirow{3}{*}{$47-100$} \\
\hline & Good (51-75) & $2(5,3)$ & & \\
\hline & $\begin{array}{l}\text { Very good } \\
(76-100)\end{array}$ & $34(92)$ & & \\
\hline \multirow{2}{*}{$\begin{array}{l}\text { Evaluation of communication with } \\
\text { hospice staff }\end{array}$} & Good (51-75) & $2(5,3)$ & \multirow[b]{2}{*}{$89,32^{*} \pm 9,48$} & \multirow[b]{2}{*}{$65-100$} \\
\hline & $\begin{array}{l}\text { Very good } \\
(76-100)\end{array}$ & $35(94,7)$ & & \\
\hline \multirow[b]{2}{*}{ Evaluation of work of basic staff } & Good (51-75) & $5(13,5)$ & \multirow[b]{2}{*}{$87,12^{*} \pm 11,02$} & \multirow[b]{2}{*}{$53-97$} \\
\hline & $\begin{array}{l}\text { Very good } \\
(76-100)\end{array}$ & $32(86,5)$ & & \\
\hline \multirow[b]{2}{*}{ Evaluation of conditions of social care } & Good (51-75) & $7(18,9)$ & \multirow[b]{2}{*}{$85,15^{*} \pm 12,23$} & \multirow[b]{2}{*}{$52-100$} \\
\hline & $\begin{array}{l}\text { Very good } \\
(76-100)\end{array}$ & $30(81,1)$ & & \\
\hline \multirow{4}{*}{$\begin{array}{l}\text { Evaluation of the level of preparation } \\
\text { for child's death }\end{array}$} & Negative $(0-25)$ & $2(5,3)$ & \multirow{4}{*}{$57,52 \pm 20,13$} & \multirow{4}{*}{$21-98$} \\
\hline & $\begin{array}{l}\text { Satisfactory } \\
(26-50)\end{array}$ & $13(35,1)$ & & \\
\hline & Good (51-75) & $15(40,7)$ & & \\
\hline & $\begin{array}{l}\text { Very good } \\
(76-100)\end{array}$ & $7(18,9)$ & & \\
\hline \multicolumn{3}{|c|}{ All domains } & $83,45^{*} \pm 10,76$ & $21-100$ \\
\hline
\end{tabular}

High level of satisfaction with hospice care, presented in this study is in accordance with other authors' observations, however, there are small number of studies concerning PPC at home. $[4,10,15,18]$ Respondents highly evaluated communication with hospice staff, what is similar to results of the research conducted previously among staff of HHChLR. [24] Many studies showed that family-staff communication issues are the central aspects of palliative care and a measurement of its is an integral part of complex evaluation of palliative care quality.[4,25-28] Results of other authors' studies showed that parents have emphasized the importance of receiving complete and honest information and having continuous and open access to staff.2. [29-31]

The loss of a child is one of the most stressful life events possible and it is controversial that care provided during the process of dying in comparison with other evaluated domains received low scores. On the one hand it is hard to expect full family preparation for child's death, on the other hand it is duty of hospice team to prepare family for premature and inevitable death of their child. [4,32-33] Nevertheless a positive observation is the high evaluation of attendance of hospice team during the child's death.
The definition of palliative care includes social support for patients. In presented study domain which evaluated conditions of social care received the lowest score among domains classified as "very good". It should be emphasized that social support is not covered by medical insurance and must be funded from other sources - often with the hospice's own resources. Katz et al [34] stated that parents of children with cancer feel more satisfied with social support than parents of chronically ill children, but in this study such relationships were not observed.

Contact with the child's family can not finish at the moment of child's death because it is the most difficult and painful time for them. Many studies identified contact with staff and with other parents who lost child as important for bereaved parents. [18, $25,26,28]$ According to results of this study two fifths of families took part in support groups organized by the hospice.

Thelimitations of presented survey includelack of comparison with other models of palliative care as the home-based care is dominant in Poland and a small number of participants. However the survey was addressed to all bereaved parents of HHChLR. 


\section{Conclusion}

Results of presented study are the key element which determines the strategy of hospice development. Specifics of PPC require particular attention to the needs of terminal, incurable patients and people supporting them.

\section{References}

1. Himelstein BP (2006): Palliative care for infants, children, adolescents, and their families. J Palliat Med 9(1):163-181.

2. A guide to the developement of children's palliative care services (2009). Third Edition. Association for Children's Palliative Care, England.

3. Liben S, Papadatou D, Wolfe J (2008) Paediatric palliative care: Challenges and emerging ideas. Lancet 371 (9615):852-864.

4. Vollenbroich R, Duroux A, Grasser M, Brandstätter M, Borasio GD, et al (2012) Effectiveness of a pediatric palliative home care team as experienced by parents and health care professionals. J Palliat Med 15(3):294-300.

5. Knapp CA, Madden VL, Curtis CM, Sloyer PJ, Huang IC, et al. (2008) Partners in care: Together for kids:Florida's model of pediatric palliative care. J Palliat Med 11(9):1212-1220.

6. Carroll JM, Santucci G, Kang TI, Feudtner C (2007) Partners in pediatric palliative care: A program to enhance collaboration between hospital and community palliative care services. Am J Hosp Palliat Care 24(3):191-195.

7. Toce S, Collins MA (2003) The FOOTPRINTS model of pediatric palliative care. J Palliat Med; 6(6):989-1000.

8. Robbins M (1998) Evaluating palliative care. Oxford University Press.

9. McWhinney I, Bass M, Donner A (1994) Evaluation of a palliative care services: problems and pitfalls. BMJ 309(6965):1340 - 1342.

10. Contro NA, Larson J, Scofield S, Sourkes B, Cohen HJ (2002) Family perspectives on the quality of pediatric palliative care. Arch Pediatr Adolesc Med 156(1):14-19.

11. Dangel T, Fowler-Kerry S, Karwacki M, Bereda J (2000) An evaluation of home palliative care program for children. Amb Child Health 6(2):101114

12. Aspinal F, Addington-Hall J, Hughes R, Higginson IJ (2003) Using satisfaction to measure the quality of palliative care: a review of the literature. J Adv Nurs 42(4):324-339.

13. Widger KA, Picot C (2008) Parents' perceptions of the quality of pediatric and perinatal end-of-life care. Pediatr Nurs 34(1):53-58

14. Korzeniewska A, Przysło Ł, Filipiak E, Grzelewska A, Stolarska M(2006) Demand for palliative home care for children in Lodz Region. Ped Pol 11:799-805.

15. de Haes J, Olschewski M, Fayers $\mathrm{P}(2010)$ Measuring the quality of life of cancer patients with the Rotterdam Symptom Checklist (RSCL). Northen Centre for Health Care Research. University of Groningen 1996.

16. Dickens DS (2010) Comparing pediatric deaths with and without hospice support. Pediatr Blood Cancer 54(5):746-750

17. Hays RM, Valentine J, Haynes G, Geyer JR, Villareale N et al. (2006) The Seattle Pediatric Palliative Care Project: effects on family satisfaction and health-related quality of life. J Palliat Med 9(3):716-728.
18. Feudtner C, Carroll KW, Hexem KR, Silberman J, Kang TI, et al (2010): Parental hopeful patterns of thinking, emotions, and pediatric palliative care decision making: a prospective cohort study. Arch Pediatr Adolesc Med 164(9):831-839.

19. Feudtner C, Hays RM, Haynes G, Geyer JR, Neff JM, et al. (2001) Deaths Attributed to Pediatric Comlex Chronic Conditions: National Trends and Implications for Supportive Care Services. Pediatrics 107(6):E99.

20. Serwint JR, Nellis ME (2005) Deaths of Pediatric Patients: Revelance to Their Medical Home, an Urban Primary Care Clinic. Pediatrics 115(1):5763.

21. Feudtner C, Feinsein JA, Satchell M, Zhao H, Kang TI (2007) Shifting Place of Death Among Children With Complex Chronic Conditions in the United States, 1989 - 2003. JAMA 297(24):2725-2732.

22. Fraser LK, Miller M, Draper ES, McKinney PA, Parslow RC (2011) Paediatric Intensive Care Audit Network: Place of death and palliative care following discharge from paediatric intensive care units. Arch Dis Child 96(12):1195-1198.

23. Bradshaw G, Hinds PS, Lensing S, Gattuso JS, Razzouk BI (2005) Cancerrelated deaths in children and adolescents. J Palliat Med 8(1):86-95.

24. Korzeniewska-Eksterowicz A, Przysło $Ł$, Grzelewski T, Stolarska M, Młynarski W et al. (2010) Job satisfaction among health professionals of Home Hospice for Children of Lodz Region. Adv Pall Med 9(3):67-72.

25. Hsiao JL, Evan EE, Zeltzer LK (2007) Parent and child perspectives on physician communication in pediatric palliative care. Palliat Support Care 5(4):355-365.

26. D’Agostino NM, Berlin-Romalis D, Jovcevska V, Barrera M (2008) Bereaved parents' perspectives on their needs. Palliat Support Care 6(1):33-41.

27. Knapp CA, Madden VL, Curtis CM, Sloyer P, Shenkman EA (2010) Family support in pediatric palliative care: how are families impacted by their children's illnesses? J Palliat Med 13(4):421-426.

28. Wolfe J, Hammel JF, Edwards KE, Duncan J, Comeau M et al. (2008) Easing of suffering in children with cancer at the end of life: is care changing? J Clin Oncol 26(10):1717-1723.

29. Meyer EC, Ritholz MD, Burns JP, Truog RD (2006) Improving the quality of end-of-life care in the pediatric intensive care unit: parents' priorities and recommendations. Pediatrics 117(3):649-657.

30. Heller KS, Solomon MZ (2005) for the Initiative for Pediatric Palliative Care (IPPC) Investigator Team: Continuity of care and caring: what matters to parents of children with life-threatening conditions. J Pediatr Nurs 20(5):335-346

31. Seecharan GA, Andresen EM, Norris K, Toce SS (2004) Parents' assessment of quality of care and grief following a child's death. Arch Pediatr Adolesc Med 158(6):515-520.

32. Wheeler I (2001) Parental bereavement: the crisis of meaning. Death Stud 25(1):51-66.

33. Ginzburg K, Geron Y, Solomon Z (2002) Patterns of complicated grief among bereaved parents. Omega J Death Dying 45:119-132.

34. Katz S (2002) When the child's illness is life threatening: impact on the Parents. Pediatr Nurs 28(5):453-463. 